módszerekkel a meghatározásához, sốt maga a fogalom is sokféleképpen (és hozzátehetjük, gyakran az egyes értelmezések összekeveredve) jelentkezik a szakirodalomban. Ha a szükséglet (és annak területi elosztása) nem ismert, az sem mondható meg, hogy mekkora része maradt kielégitetlen - a mérhetô igénybevételhez viszonyítva.

További megválaszolatlanul maradt kérdéseink sem a szerzóknek róhatók fel - az egészségügy-földrajz jelenlegi állapotából fakadnak. Ezek közül egyet emelünk ki: az igénybevételt befolyásoló nem-területi tényezók is (társadalmi réteg, életkor stb.) jelentôs területi különbségeket mutatnak. Hogyan fonódnak össze ezek a területi különbségek a földrajzi természetư tényezốk különbségeivel, illetve melyik játssza a meghatározó szerepet az elérhetôség területi különbségei alakításában?

A könyv utolsó fejezete az egészségügyi tervezés területi vonatkozásait tárgyalja, bemutatva a lehetséges stratégiákat és néhány konkrét gyakorlati példát a területi problémák kezelésére.

A szerzők az előszóban hangsúlyozzák, hogy könyvük részben az orvosföldrajz egyetemi oktatása számára íródott. Az ilyen jellegú speciális kurzusok - ha lennének -, Magyarországon is hasznosítani tudnák a könyvet.

Az egészségügyföldrajzzal való további ismerkedést megkönnyítheti a könyv közel 500 tételt tartalmazó irodalomjegyzéke is.

Orosz Éva

\title{
SZENTI TIBOR: PARASZTVALLOMÁSOK
}

\author{
(Gondolat; Budapest, 1985390 p.)
}

SZENTI TIBORt 1979-ben megjelent „A tanya" c. múve avat ta igazi néprajzkutatóvá, ez a szakmai elismerés mellett szép közönségsikert is hozott számára. Ez a kezdet visszatérésre kötelez. Ưj könyve: fốhajtás a vásárhelyi parasztember elött.

A dél-alföldi tanyás város népéletének megrajzolását már a neves etnográfus, KISS LAJOS (1881-1965) tervbe vette. A szegényparasztság társadalomrajzával - ,A szegény emberek élete" (Bp. 1955) - el is készült, halála azonban megakadály ozta abban, hogy vállalkozását a középbirtokos gazdaréteg életmódjának bemutatásával teljessé tegye. SZENTI TIBOR munkája - noha Hódmezővásárhely néprajzi szempontból korántsem föltáratlan terület - több egyszerú, hiányt pótló folytatásnál.

„Parasztvallomások" - ígéri a cím. Kik vallanak hát, hogyan és miról? Századunk első felének vásárhelyi gazdatársadalmát zömmel kis- (5-20 hold) és középbirtokosok (20100 hold) alkották, akik, ha más-más szinten is, de a hagyományos tanyai parasztéletmódot élték. Amit e könyv ôriz: közel ötven képviselōjük tudás- és élményanyaga. Mivel a gazdacsalád vagyona fölött $a z$ apa rendelkezett, $s$ a termelést is ö irányitotta, nem meglepô, hogy jórészt fér- fiak emlékeznek. Hetven-nyolcvan felé járó idős emberek szinte valamennyien - az öregkor bölcsességével és megnyugvásával visszatekin tők. Megszólítani óket! Az etnográfus kutatói mentalitása példaadó: illő alázattal, egyéniségưk tiszteletben tartásával fordul hozzájuk $-\mathbf{s}$ a bizalmukkal tisztelik meg érte. Még a magnetofon, az interjú jellegứ anyaggyứjtés bevett segédeszköze sem áll ember és ember közé; ha mégoly sok időt, fáradságos gondot és türelmet igényel is a kézzel történỏ lejegyzés. Adott azonban a könyvbe gyưjiött szavak hitelét biztosító , parasztlektorálás” lehetősége. Ugyanaz leírva is, mint elmondva? A szerző által továbbfejlesztett módszer nagy értéke, hogy a kérdezettek névtelen ,adatközlök" helyett a szó szoros értelmében vallomástevốk, az alkotás folyamatának aktív résztvevői lehetnek. Az olvasó számára így válik érthetővé, hogy a családi hagyományok, valós élethelyzetek, racionális tapasztalatok - azaz a viszonylag egyszerüen átadható ismeretanyag - mellett a paraszti lét értelmét summázó, soha ki nem mondott ,hitvallások" is utat találhattak a kérdezóhöz. O megérti és közvetíteni tudja ezt az üzenetet!

„Mélyfúrással rést nyitottam egy múltba veszó világba" - fogalmazza meg bevezetôjében 
SZENTI TIBOR. Ami felszínre kerül: ègy eltünt társadalmi réteg megfogyatkozott szellemi öröksége. Az etnográfus a szóbeli vallomásokon kívül a paraszti írásbeliség fölkutatott emlékeibớl igyekszik rekonstruálni ezt a hagyatékot, de hogy minél pontosabb, minél teljesebb legyen, él a helytörténeti források, korabeli térképek, ház-alaprajzok és fényképek adta lehetóségekkel is. Mozaikokból építkezik tehát, mégis mind a 14 fejezet megkomponált egész. A hiteles "paraszti müvelödéstörténethez" bóséges jegyzetanyag, elmélyüllt kutatómunkáról tanúskodó "mini tájszótár" s a legalapvetớbb muiveket tartalmazó szakirodalmi tájékoztató ad útmutatást. (Aki a kezdóbetúk olvastán nem röstell mindig hátralapozni, még a vallomástevóket is azonosíthatja a Függelékben található névjegy zék alapján. A pródonként összeáll így egy-egy emberélet története.)

Teljességre törekvő paraszti rétegvizsgálata eredményeit tematikus elrendezésben tárja elénk a szerző. Gondolatmenetét - már csak az idézett vallomástöredékek varázsáért is - érdemes megismerni!

\section{Történelmi emlékezet}

(, ,Mindég a parasztot vitték a tûzvonalba, és azt nem sajnálta sönki. Hó lepte, akna roncsolta, golyó fogta. A paraszt, aki termelt, aki éjt nappallá téve dolgozott, hogy eltartsa a nemzetet, ó volt a történelöm, a háborúk martaléka." 56. o.)

Kiindulópont: az idóhatárok és a földrajzi keretek megrajzolása. A múltidézés ennek megfelelően a népi emlékezet különböző valóságértékü szféráihoz kapcsolódik: 1) a nemzedékról nemzedékre hagyományozott mondai világ, 2) az ősök, a déd-és nagyszülók révén átfogható idő,3) a két világháború által meghatározott személyes élmények. Külön fejezet foglalkozik a nemzeti múlt emlékeinél is értékesebb, ám mind ez ideig kevés figyelemre méltatott paraszti helytörténet problémakörével. Szenti Tibor tudakozódása nyomán eddig ismeretlen nézőpontból tárul föl előttünk mezôváros és határa, továbbgondolásra érdemes szempontokat adva történésznek és a települések belsó szerkezetét kutató geográfusnak egyaránt.

\section{Család, mũveltség, gazdálkodás}

(, Úgy tartották, hogy Amég a vásárhelyi gazda az agyban a lábát föl tudja emelni, nem irat sömmit a fiaira." 116 . o.)

$\mathrm{Az}$ általánosan elfogadott közösségi normák és a különc egyediség sajátos kettőssége ,,szocionéprajzi" megközelítésben - ez a második nagy gondolatkör summázata.

A nemzedékeket egységbe fogó gazdanagycsalád a termelés szervezeti kereteként $s$ mintaadó szúkebb közösségként jelenik meg. Az összetartozás igazi erejét az anya, nagyanya szeretete biztosította, míg a gazdaság irányítása, vagyona révén, a családfó kezében összpontosult. Az emlékezó parasztember most válik csak igazán szakértővé, lett légyen szó a határhasználat rendjéről, a termelési folyamatok egymásutánjáról, a cselédek rangsoráról vagy akár a tanya és a városi ház kapcsolatáról.

„Különös parasztok - furcsa szokások." Eletteli történetek következnek „tanyai donquijotékról"; gőgös, vagyont herdáló vagy éppen fukar gazdákról; idevetődött vándorokról félelmet keltố vagy nevetésre ingerlő idegenek itt valahányan. Egészen más - mert elfogadott - az átlagnál érzékenyebb lelki alkatú versfaragó parasztok világa.

\section{A test és a lélek tükre}

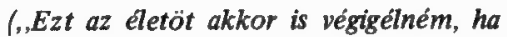
újra születnék, mert az igazi boldogságot csak a földtül löhet mögkapni. Nem csuda, hogy anyaföldnek hivjäk, mert az anya és a föld adta szeretet egyazon boldogság." 355. o.)

A befejező rész központi gondolata: az élet csodája. Megóvásának vágya, az egészség, a munkaképesség visszaszerzésének igénye nemzedékek gyógyító tapasztalatait érlelte tudássá Vásárhelyt is. A szerzőnek valóságos kis gyưjteményt sikerült összeállítania az embert gyötrő, állatot kínzó nyavalyák orvoslására szolgáló népi receptekból.

Bölcső, nászágy, koporsó - az emberélet fordulóinak ismert kellékei. Az újszülött fogadása és a halott búcsúztatása nem tér el lényegesen más református vidékek hagyományaitól. Annál többet mond azonban a szerelmi élet benső titkainak föltárása. Szenti Tibor szinte példa nélkül álló vállalkozása a szemérmes hallgatás világába enged bepillantást. 
Mi adja meg az élet értelmét? A kérdésre - a számvetést készítoo öregek sajátos filozófiájával - sosem hallott paraszti ,,ars poeticákban" fogalmazód nak meg a válaszok. Nemcsak a néprajzosokhoz szól, s nemcsak a vásárhelyieké ez a könyv. Amit irója vállalt: az emlékezettel még éppen elérhetố parasztmúlt emberi értékeinek átmentése. Ěrtük és általuk, akik sorsként élték meg azt - mindannyiunknak, hogy merítsünk belöle. Mert az üzenet így hangzik: ,A mi sorsunk a halálunkkal lezárul, de mégis folytatódik tovább, mert gyerökök születtek. A szülók, az embörök a gyerö. keikben élnek majd tovább." (338. o.)

Legyen ez ajánlás valamennyi társadalomkutató számára.

Duró Annamária

\title{
FRISNYÁK SÁNDOR: TÖRTÉNETI FÖLDRAJZ
}

\author{
(Szabolcs-Szatmár megyei Pedagógus Továbbképzó Intézet; Nyíregyháza, 1985. 390 p.)
}

A könyv a szerző „Adalékok a SzatmárBeregi síkság, a Rétköz, a Nyirség és a Zempléni-hegység történeti földrajzához (XVIIIXIX. század)" c. kandidátusi ér tekezése alapján készült. A vizsgált mintaterületek eltérő jellege (alföldi és hegységi) módot ad annak bemutatására, hogy a különböző környezettípusok mint a társadalmi termelés állandó és szükségszerú feltételei - többféle termelési-gazdasági tér kialakulását segítették elő. Az, ,időkeresztmetszet" (a XVIII-XIX. század) kiválasztását a földrajzi környezet átalakulásának felgyorsulása, a természeti képben és a társadalmi-gazdasági szférában bekövetkezett változások magyarázzák.

A történeti földrajznak két ága van. Az egyik a topográfiai rekonstrukció, amellyel a historikusok foglalkoznak. Ez a jelenségek és folyamatok térbeli regisztrálására törekszik. A geográfusok által müvelt önálló történeti földrajz feladata a földrajzi környezet (valamely szintû regionális egység) múltbeli állapotának komplex geográfiai feltárása és értékelése. A történeti földrajz - véli a szerző - a gazdaságföldrajz önálló tudományága, ugyanúgy mint az ipar-, az agrár-, a településföldrajz stb. Azonban Magyarországon a történeti földrajz mindmáig kevésbé múvelt tudomány, s e müfajban elért eredmények nagy része a történészek érdeme. Magyarország történeti földrajzának feldolgozása a makroregionális vizsgálatok eredményeire kell hogy épüljön. Mivel nagytáj-szintü történeti földrajzi munkák még nem állnak rendelkezésre, mezo- és mikrotér ségek kutatása látszik reális feladatnak. Ennek a koncepciónak az értelmében született meg ez a munka is. A szerző kutatásai során a források széles körét használta fel, köztük elsôsorban a történeti földrajz speciális forrásait (írott emlékek, íratlan szellemi hagyatékok, földrajzi nevek, régi kéziratos és nyomtatott térképek, látképek, rajzok, fényképek, tárgyi emlékek). A forrásanyag feldolgozása során alkalmazni kellett a történeti földrajzban ismert metodikai eljárásokat, így a reduktiv (egyszerüsítô), a retrospektív (visszaf lé vizsgáló), retrogressziv (visszaf elé haladó) és különösen a komparativ (összehasonlító) módszert. Ez utóbbi lehetôvé teszi, hogy egy-egy korszak értékelése ne szakadjon el az akkor adott fejlődési színvonaltól, az akkori társadalmi, gazdasági és politikai hatótényezôktốl.

A könyv a földrajztudományban klasszikusan alkalmazott logikai menetet követi. Első érdemi fejezete az említett területek XVIII. századi ősi, folyószabályozás és belvízrendezés elốtti állapotát tárja elénk. Az olvasó sok érdekességet, részletekre is kiterjedô leírást, korabeli rajzolt térképeket talál e vidékek XVIII. századi természetföldrajzi és elsősorban hidrogeográfiai képéről. Nagyon karakteresen jelentkezik a társadalom természetátalakító szerepe és ereje a XIX. század folyamán az alföldi térségek példáján (belvízrendezés, folyószabályozás stb.). A hegyvidéki mintaterület természetföldrajzi képe az egymásra épülő kultúrák nyomán kisebb változáson ment keresztül, mint síksági környezete.

A következőkben a szerzó a termelés társadalmi-gazdasági feltételeit elemzi, elhelyezi a térséget a vizsgált idôszak szükebb és tágabb 